\title{
Latitudinal distributions of organic nitrogen and organic carbon in marine aerosols over the western North Pacific
}

\author{
Y. Miyazaki ${ }^{1}$, K. Kawamura ${ }^{1}$, J. Jung ${ }^{2}$, H. Furutani ${ }^{2}$, and M. Uematsu ${ }^{2}$ \\ ${ }^{1}$ Institute of Low Temperature Science, Hokkaido University, Sapporo, Japan \\ ${ }^{2}$ Atmospheric and Ocean Research Institute, The University of Tokyo, Kashiwa, Japan \\ Received: 14 October 2010 - Published in Atmos. Chem. Phys. Discuss.: 23 November 2010 \\ Revised: 17 March 2011 - Accepted: 27 March 2011 - Published: 1 April 2011
}

\begin{abstract}
Marine aerosol samples were collected over the western North Pacific along the latitudinal transect from $44^{\circ} \mathrm{N}$ to $10^{\circ} \mathrm{N}$ in late summer 2008 for measurements of organic nitrogen (ON) and organic carbon (OC) as well as isotopic ratios of total nitrogen (TN) and total carbon (TC). Increased concentrations of methanesulfonic acid (MSA) and diethylammonium (DEA ${ }^{+}$) at $40-44^{\circ} \mathrm{N}$ and subtropical regions $\left(10-20^{\circ} \mathrm{N}\right)$ together with averaged satellite chlorophyll- $a$ data and 5-day back trajectories suggest a significant influence of marine biological activities on aerosols in these regions. ON exhibited increased concentrations up to $260 \mathrm{ngN} \mathrm{m}^{-3}$ in these marine biologically influenced aerosols. Water-insoluble organic nitrogen (WION) was found to be the most abundant nitrogen in the aerosols, accounting for $55 \pm 16 \%$ of total aerosol nitrogen. In particular, the average WION/ON ratio was as high as $0.93 \pm 0.07$ at $40-44^{\circ} \mathrm{N}$. These results suggest that marine biological sources significantly contributed to $\mathrm{ON}$, a majority of which is composed of water-insoluble fractions in the study region. Analysis of the stable carbon isotopic ratios $\left(\delta^{13} \mathrm{C}\right)$ indicated that, on average, marine-derived carbon accounted for $\sim 88 \pm 12 \%$ of total carbon in the aerosols. In addition, the $\delta^{13} \mathrm{C}$ showed higher values (from -22 to $-20 \%$ ) when ON/OC ratios increased from 0.15 to 0.35 in marine biologically influenced aerosols. These results clearly show that organic nitrogen is enriched in organic aerosols originated from an oceanic region with high biological productivity, indicating a preferential transfer of nitrogen-containing organic compounds from the sea surface to the marine atmosphere. Both WION concentrations and WION/water-insoluble organic carbon (WIOC) ratios tended to increase with increas-
\end{abstract}

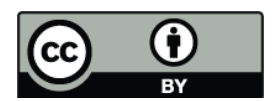

Correspondence to: Y. Miyazaki (yuzom@lowtem.hokudai.ac.jp) ing local wind speeds, indicating that sea-to-air emissions of ON via sea spray contribute significantly to the marine organic aerosols over the study region.

\section{Introduction}

Marine aerosol, composed of primary and secondary inorganic and organic components, contributes to the Earth's radiative forcing and indirectly to biogeochemical cycling of carbon and nitrogen and thus influences marine ecosystems. The ocean is the largest source of natural reduced sulfur gas to the atmosphere, most of which is in the form of dimethylsulfide (DMS). DMS derived from phytoplankton is a biogenic precursor gas for sulfate $\left(\mathrm{SO}_{4}^{2-}\right)$ aerosols that alter the Earth's radiative forcing directly by scattering solar energy and indirectly by acting as cloud condensation nuclei (CCN) (Ayers and Gras, 1991). A potential oceanic organic carbon (OC) in marine aerosol has also long been recognized based on significant OC concentrations observed at oceanic sites (e.g., O'Dowd et al., 2004). Recent studies have demonstrated that the chemical composition of marine organic aerosol is the complex result of different primary and secondary sources (Facchini et al., 2008a; Hawkins and Russell, 2010; Rinaldi et al., 2010). Primary emissions of biogenic organic matter via sea spray have been suggested as potential mechanisms by which phytoplankton can modulate chemical and physical properties of marine aerosols and clouds. In previous observations of marine primary organic aerosol (POA), its chemical characterizations showed hydrophobic, polysaccharide-like material (e.g., Hawkins et al., 2010) or micro-organisms such as bacteria and diatoms (Leck and Bigg, 1999; Aller et al., 2005). Moreover, the formation mechanisms of secondary organic aerosol (SOA) in

Published by Copernicus Publications on behalf of the European Geosciences Union. 
the marine atmosphere have not been fully clarified. Hence, global emission of oceanic OC aerosols is still highly uncertain (Spracklen et al., 2008; Myriokefalitakis et al., 2010; Vignati et al., 2010).

Organic nitrogen $(\mathrm{ON})$ compounds are subjected to chemical transformations in the troposphere, forming products that may potentially influence the chemical and physical properties of atmospheric aerosols (e.g., Zhang et al., 2002). Despite the importance of ON in marine biogeochemical cycles and its critical role in the atmosphere, the origins and chemical composition of $\mathrm{ON}$ in marine aerosols are largely unknown because of very limited field research (Duce et al., 2008). In addition, the relative importance of direct emissions and secondary formation of $\mathrm{ON}$ is unclear. The most identified category of $\mathrm{ON}$ in aerosols is reduced nitrogen $(\mathrm{N})$ compounds, which include amino acids (Milne and Zika, 1993), alkyl amines (e.g., Ge et al., 2011a), urea, and $\mathrm{N}$-heterocyclic compounds that originate from biomass burning (Mace et al., 2003), animal husbandry (Schade and Crutzen, 1995), and the ocean surface (Matsumoto and Uematsu, 2005). Shi et al. (2010) reported that urea accounted for $\sim 8 \%$ of water-soluble $\mathrm{ON}$ on average over the eastern edge of China, where air masses were frequently affected by anthropogenic sources.

Regarding aerosol water-soluble organic nitrogen (WSON) in marine atmosphere, Facchini et al. (2008b) found high concentrations of dimethylamine and diethylamine in sub-micrometer marine aerosols in the North Atlantic, pointing to the importance of alkylamines as a biological SOA tracer. They showed that alkyl-ammonium salts represented on average $11 \%$ of the marine SOA and a dominant fraction (35\% on average) of aerosol WSON in the North Atlantic. Moreover, the amine concentrations measured over the North Atlantic Ocean have shown distinct seasonal variation, indicating that the production of amine is most likely influenced by the primary productivity of phytoplankton (Facchini et al., 2008a; Müller et al., 2009). Previous studies have mostly focused on the water-soluble fractions of $\mathrm{ON}$, whereas the abundances, sources, and relative importance of water-insoluble organic nitrogen (WION) compared to WSON have not been previously investigated in marine aerosols. Miyazaki et al. (2010a) found that average bulk ON concentrations were two times greater in aerosols collected in an oceanic region with higher biological productivity than in regions with lower productivity, suggesting the importance of the total aerosol ON that is linked to oceanic biological activity.

Here we present, for the first time, latitudinal distributions of both water-soluble and water-insoluble fractions of $\mathrm{ON}$ in marine aerosols collected over the western North Pacific in summer when marine biological activity is high. The objective of the present study is to understand the abundance and sources of the aerosol ON (for water-soluble and waterinsoluble fractions) as well as the aerosol OC associated with marine biological activity. We present the latitudinal distri- butions of ON and OC and their isotopic ratios to better discuss the relative importance of marine biological sources of organic aerosols.

\section{Experimental}

\subsection{Aerosol sampling}

Aerosols were sampled during the R/V Hakuho-maru cruise (KH08-2) from Kushiro $\left(42.98^{\circ} \mathrm{N}, 144.37^{\circ} \mathrm{E}\right)$ to Tokyo $\left(35.65^{\circ} \mathrm{N}, 139.77^{\circ} \mathrm{E}\right)$, Japan, in the western North Pacific from $44^{\circ} \mathrm{N}$ to $10^{\circ} \mathrm{N}$ along $155^{\circ} \mathrm{E}$, which covers the subarctic to subtropical region (Fig. 1). Aerosol samplings were conducted between 24 August and 13 September 2008. During most of the sampling period, the weather was fine with very few rainfall events ( $<6 \%$ of the total sampling time). Together with the cruise track, Fig. 1 also presents typical 5day back trajectories and average concentrations of satellitederived chlorophyll- $a$ during August and September 2008 obtained from SeaWiFS satellite data. The trajectories were calculated for air masses starting from the mid-points of each sampling at altitudes of 50,100, and $200 \mathrm{~m}$. For the calculation, we used the NOAA Hybrid Single-Particle Lagrangian Integrated Trajectory (HYSPLIT) model (http://www.arl. noaa.gov/ready/hysplit4.html, NOAA Air Resources Laboratory, Silver Spring, MD, USA). The air masses were transported mainly from the eastern-to-central Pacific due to the Pacific high-pressure system, as shown by most of the back trajectories. Moreover, the trajectories suggest that most of the air masses were transported within the marine boundary layer. The oceanic regions are suitable to study the influences of oceanic emissions on marine aerosols.

A high-volume air sampler was located at the upper deck of the ship and used to collect ambient aerosol samples. The samplings were made using quartz fiber filters $(25 \times 20 \mathrm{~cm})$ at a sampling flow rate of $1000 \mathrm{~L} \mathrm{~min}^{-1}$. The average total volume of the samples was $900 \mathrm{~m}^{3}$. The samples were collected on precombusted $\left(450^{\circ} \mathrm{C}, 3 \mathrm{~h}\right)$ quartz filters and were stored individually in glass jars with a Teflon-lined screwed cap at $-20^{\circ} \mathrm{C}$ prior to analysis. The sampling time for each sample was approximately $12 \mathrm{~h}$, starting at 08:00 LT and 20:00 LT, which are referred to as daytime and nighttime samples, respectively. Possible contamination from ship exhaust was prevented by shutting off the sampling pump during beam-side airflow and/or low wind speeds $\left(<5 \mathrm{~m} \mathrm{~s}^{-1}\right)$, resulting in an effective pumping time of about $87 \%$ of the sampling period. Additionally, the aerosol data with a total air volume $<800 \mathrm{~m}^{3}$ were omitted in the current analysis, because these aerosol samples might have been affected by local contamination in stagnant air. Indeed, these data correspond well with time-series of substantially high aerosol number concentrations measured by a water-based condensation particle counter (CPC) (Mochida et al., 2011), presumably caused by the ship's exhaust. As a result of the data 
screening, we present 32 samples for the data analysis out of the total 42 samples obtained in the present study.

\subsection{Chemical analysis}

A total organic carbon (TOC)/total nitrogen (TN) analyzer (Model TOC-Vcsh, Shimadzu) was used to determine the total aerosol carbon and nitrogen that are dissolved in water. A filter cut of $19.63 \mathrm{~cm}^{2}$ was extracted with ultra-pure Milli-Q water using an ultrasonic bath $(10 \mathrm{~min} \times 3$ times $)$. The total extracts were then filtrated with a disc filter (Millex-GV, $0.22 \mu \mathrm{m}$, Millipore, Billerica, MA, USA) followed by injection of dissolved OC and TN in the extracts into the analyzer. The sample was first injected into a combustion tube in the analyzer, which is filled with an oxidation catalyst (fiber platinum on quartz) and heated to $720^{\circ} \mathrm{C}$ to derive $\mathrm{CO}_{2}$ and nitrogen monoxide under a constant flow of ultra-pure air. The combustion gases that passed through an electrical dehumidifier for cooling and dehydration and then through a halogen scrubber were measured by a nondispersive infrared (NDIR) detector to determine the derived $\mathrm{CO}_{2}$. The measured carbon is defined here as water-soluble organic carbon (WSOC). After passing through the NDIR detector the gas stream was directed to the TN unit, which provided the TN content of the liquid sample. The nitrogen content was determined by measuring nitrogen monoxide with an ozone chemiluminescence detector. Because the instrument measures TN in liquid sample, we use the term water-soluble total nitrogen (WSTN) when referring to the concentrations measured with this instrument. Field blanks for WSOC and WSTN dissolved in water were $70 \pm 8 \mu \mathrm{gC} \mathrm{L}^{-1}$ and $40 \pm 5 \mu \mathrm{gNL}^{-1}$, respectively. These values represent $24 \%$ and $28 \%$ of the average WSOC and WSTN concentrations in ambient aerosols, respectively. The data presented here were corrected for blanks. The total uncertainties of the WSOC and WSTN concentrations were estimated to be $15 \%$ and $12 \%$, respectively.

An aliquot of filter sample was analyzed for total nitrogen (TN) and total carbon (TC) using an elemental analyzer (EA) (NA 1500, Carlo Erba) (Kawamura et al., 2004). Nitrogen and stable carbon isotopic analyses were also conducted using the same EA interfaced to an isotope ratio mass spectrometer (Finnigan MAT Delta Plus) for $\delta^{15} \mathrm{~N}$ and $\delta^{13} \mathrm{C}$ measurements (Kawamura et al., 2004). The concentrations and isotopic ratios reported here were corrected against the field blanks using isotope mass balance equations (Turekian et al., 2003). The blank levels of TN and TC were $22 \%$ and $10 \%$ of the measured concentrations, respectively. The nitrogen and carbon isotope corrections were $0.9 \%$ and $0.5 \%$, respectively. Some of the samples were analyzed in duplicate. The uncertainties of TN and TC measurements were within $9 \%$ whereas those of the $\delta^{15} \mathrm{~N}$ and $\delta^{13} \mathrm{C}$ measurements were about $0.5 \%$.

Mass concentrations of $\mathrm{OC}$ and elemental carbon (EC) were measured using a Sunset lab OC/EC analyzer. A filter punch of $1.54 \mathrm{~cm}^{2}$ was used for the analysis of

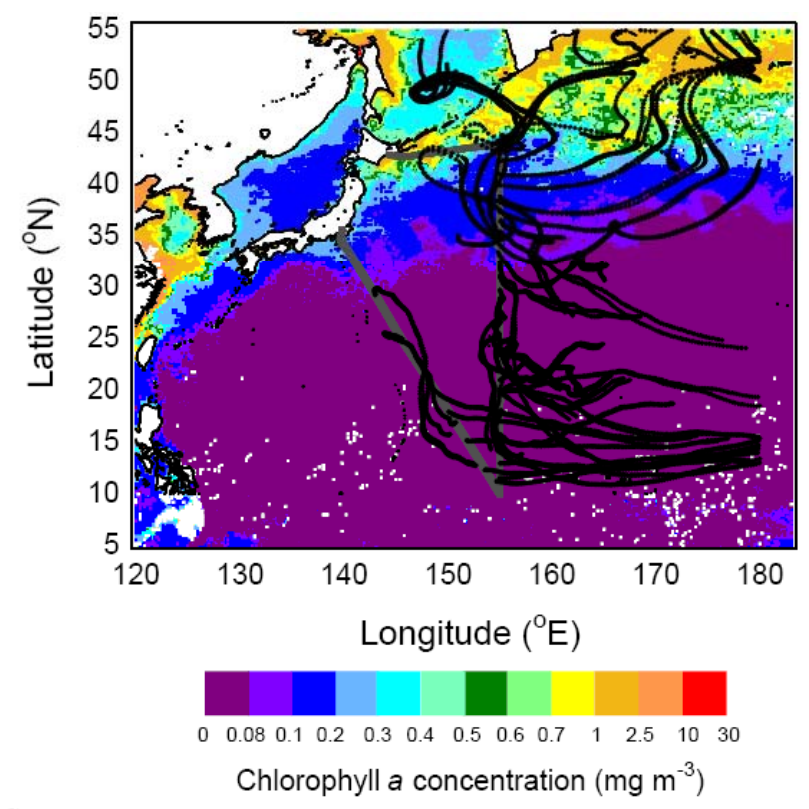

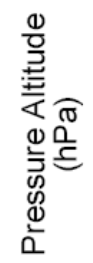

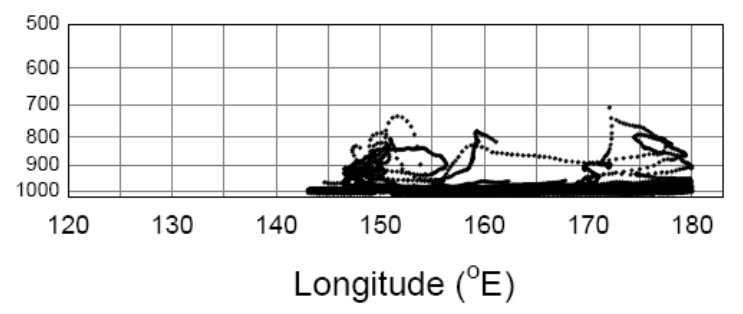

Fig. 1. $R / V$ Hakuho cruise track in the western North Pacific between 24 August and 13 September 2008, together with typical 5day back trajectories. Also shown are monthly averaged concentrations of chlorophyll- $a$ for August-September 2008 derived from SeaWiFS data, available from the NASA Goddard Space Flight Center/Distributed Active Archive Centers. A white dot indicates that the satellite data is missing at a corresponding grid.

$\mathrm{OC}$ and EC. The equivalent $\mathrm{OC}$ concentration from field blanks accounted for $\sim 18 \%$ of the average OC concentrations of the actual samples. OC data were all corrected against field blanks. Based on filter blank uncertainties, detection limits for $\mathrm{OC}$ and $\mathrm{EC}$ were about $100 \mathrm{ngC} \mathrm{m}^{-3}$ and $20 \mathrm{nC} \mathrm{m}^{-3}$, respectively, for the sampling and analytical conditions here. TC values measured by the $\mathrm{OC} / \mathrm{EC}$ analyzer $(\mathrm{TC}=\mathrm{OC}+\mathrm{EC})$ agreed with those obtained by the EA within $5 \%\left(r^{2}=0.95\right.$; slope $=0.96$; intercept $=4.2 \mathrm{ngC} \mathrm{m}^{-3}$ ), which was equivalent to or less than the uncertainties of each instrument.

Another filter cut of $1.54 \mathrm{~cm}^{2}$ was extracted with MilliQ water. The total extracts $(10 \mathrm{ml})$ were then filtrated using a membrane disc filter to determine major anions and cations as well as methanesulfonic acid (MSA) by a Metrohm ion chromatograph (Model 761 compact IC). The blank levels of the major ions were below $5 \%$ of the measured concentrations. For the separation and quantification 
of diethylammonium ions $\left(\mathrm{DEA}^{+}\right)$, a filter cut of $21.2 \mathrm{~cm}^{2}$ was subject to extraction in $5 \mathrm{~mL}$ of Milli-Q water. The analysis was also performed by IC (Miyazaki et al., 2010a).

The concentration of ON was determined by subtracting the inorganic nitrogen (IN) concentration from the TN concentration measured with the EA. Here IN is defined as the sum of nitrate $\left(\mathrm{NO}_{3}^{-}\right)^{-}$, nitrite $\left(\mathrm{NO}_{2}^{-}\right)^{-}$, and ammonium $\left(\mathrm{NH}_{4}^{+}\right)$-nitrogen measured with the IC. Concentrations of WSON are defined as the difference between WSTN measured with the Shimadzu TOC/TN analyzer and IN $($ WSON $=$ WSTN - IN). Similarly, WION was defined as $\mathrm{WION}=\mathrm{TN}-\mathrm{WSTN}$. Using the propagating errors of each parameter, the uncertainties of WSON and WION were estimated to be $18 \%$ and $16 \%$, respectively.

\subsection{Conversion efficiency of water-soluble organic nitrogen compounds}

When interpreting the WSON and WION data, it is important to clarify the definitions of WSON and WION under our operating conditions of the analyzer. To characterize these fractions of $\mathrm{ON}$, we investigated the conversion efficiency of organic nitrogen compounds dissolved in water to nitrogen monoxide in the Shimadzu TOC/TN analyzer by using several authentic organic compounds. Briefly, authentic watersoluble nitrogen-containing organic species were dissolved in purified water and injected into the TOC/TN analyzer. Here we used several nitrogen-containing organic species according to differences in their functional groups or nitrogen positions in their chemical structure. Note that concentration levels of $\mathrm{N}$ in the experiments are set to be similar to those of WSON in the water extracts of ambient samples.

Table 1 summarizes the results of the experiment. The conversion efficiencies of nitrogen in L-alanine, diethylamine, anthranilamide, Suwannee River fulvic acid to nitrogen monoxide were $\sim 100 \%$. Similarly, nitrogen in 4 imidazole carboxylic acid and imidazole-2-carboxaldehyde was almost completely converted to nitrogen monoxide in the analyzer. The result demonstrates that nitrogen in these species is almost completely converted to nitrogen monoxide within the measurement uncertainty under our operating conditions. By contrast, the conversion efficiencies of nitrogen in 4-pyrazole carboxylic acid and acetohydrazide were as low as $43 \pm 14 \%$ and $11 \pm 2 \%$, respectively. Although the exact reason for the low conversion efficiencies for these compounds is unclear, both of these compounds have nitrogen atoms in adjacent positions in their molecular structure, which may have related to the lower conversion efficiency to nitrogen monoxide. Note that conversion efficiencies of carbon in all of these compounds to $\mathrm{CO}_{2}$ were $\sim 100 \%$ in the TOC analyzer. In addition, it was also confirmed that nitrogen and carbon in these authentic organic species were converted to $\mathrm{N}_{2}$ and $\mathrm{CO}_{2}$ by $\sim 100 \%$ by the EA, respectively. In summary, the laboratory experiments indicate that some classes of dissolved organic nitrogen compounds may not be quantitatively converted to nitrogen monoxide under our operating conditions of this instrument. This may lead to an underestimation of WSON and overestimation of WION if WSTN is associated with compounds that have nitrogen atoms adjacent to carbon atom.

\subsection{Air mass exposure to chlorophyll- $a$ along with back trajectory}

The trajectory positions were calculated every $1 \mathrm{~h}$ along the 5-day back trajectory. At each position along the trajectory, concentrations of chlorophyll- $a$ in the ocean were taken from monthly mean global distributions (August-September 2008) obtained from SeaWiFS observations. The SeaWiFS data used for the present analysis had horizontal resolution of 0.2 degrees $(\sim 25 \mathrm{~km})$. The average concentrations of chlorophyll- $a$ exposure were then calculated along each trajectory to produce a time series of average air mass exposure to chlorophyll- $a$ along the cruise track. The trajectories were ended at two altitude levels (50 and $100 \mathrm{~m}$ ), and chlorophyll$a$ values were averaged for each sampling point. It is noted that the chlorophyll- $a$ concentrations at each grid may vary on shorter time scales. Moreover, the trajectories do not account for subgrid-scale wind and transport processes that may be active within the marine boundary layer.

\section{Results and discussion}

\subsection{Air-mass characteristics}

Figure 2 shows latitudinal distributions of the concentrations of MSA, nss- $\mathrm{SO}_{4}^{2-}$, and $\mathrm{NO}_{3}^{-}$. Five-day back-trajectoryweighted SeaWiFS chlorophyll- $a$ is also shown in the figure. MSA is produced by the atmospheric oxidation of DMS, which is released as a gas from marine microbial processes and thus can be used as an indicator of secondary aerosols of marine biogenic origin. MSA showed a distinct latitudinal gradient, with concentrations increasing at 40 $44^{\circ} \mathrm{N}$. In this oceanic region, the back-trajectory-weighted chlorophyll- $a$ showed a similar spatial trend to that of MSA. Back trajectories suggest that air masses sampled at 40 $44^{\circ} \mathrm{N}$ were transported within the marine boundary layer and frequently encountered oceanic regions with high productivity in a northeast upwind sector of the sampling locations (Fig. 1). Detailed analysis of the trajectory-weighted chlorophyll- $a$ showed that aerosol samples collected at 40$44^{\circ} \mathrm{N}$ must have passed over a higher chlorophyll- $a$ region approximately $12-36 \mathrm{~h}$ before reaching the ship. In addition, in-situ measured chlorophyll- $a$ in sea water showed substantially larger concentrations at $40-44^{\circ} \mathrm{N}$ (av. $0.56 \mathrm{mg} \mathrm{m}^{-3}$ ) compared to those at $10-40^{\circ} \mathrm{N}\left(0.05-0.15 \mathrm{mg} \mathrm{m}^{-3}\right)$ (Ooki et al., 2010). These results suggest that the aerosols sampled at $40-44^{\circ} \mathrm{N}$ were largely influenced by oceanic emissions from both upwind regions with high productivity and local emissions from marine biological sources. 
Table 1. Conversion efficiencies of selected water-soluble nitrogen-containing organic compounds to nitrogen monoxide during the measurements by the Shimadzu TOC/TN analyzer. Note that conversion efficiencies of carbon in all of these compounds to $\mathrm{CO}_{2}$ were $\sim 100 \%$.

\begin{tabular}{|c|c|c|c|}
\hline Compounds & $\begin{array}{c}\text { Molecular } \\
\text { structure }\end{array}$ & $\begin{array}{l}\mathrm{N} \text { concentrations }{ }^{\mathrm{a}} \\
\left(\mu \mathrm{gNL}^{-1}\right)\end{array}$ & $\begin{array}{l}\text { Conversion } \\
\text { efficiency of } \mathrm{N}(\%)\end{array}$ \\
\hline L-Alanine & & 1120 & $101 \pm 2$ \\
\hline Diethylamine & & 1345 & $100 \pm 2$ \\
\hline Anthranilamide & & 1480 & $100 \pm 3$ \\
\hline Suwannee River fulvic acid ${ }^{b}$ & - & $730^{\mathrm{c}}$ & $95 \pm 6$ \\
\hline 4-Imidazole carboxylic acid & & 1000 & $99 \pm 5$ \\
\hline Imidazole-2-carboxaldehyde & & 1160 & $101 \pm 2$ \\
\hline 4-Pyrazole carboxylic acid & & 1000,1500 & $43 \pm 14$ \\
\hline Acetohydrazide & & 1295,1660 & $11 \pm 2$ \\
\hline
\end{tabular}

a Concentration levels of $\mathrm{N}$ are set to be similar to those of WSON in the water extracts of ambient samples.

b Suwannee River fulvic acid are produced by the International Humic Substnce Society (IHSS).

${ }^{c}$ Concentrations of $\mathrm{N}$ is based on sample information for elemental analysis provided by the IHSS.

The nss- $\mathrm{SO}_{4}^{2-}$ concentrations also showed distinct peaks at $40-44^{\circ} \mathrm{N}$ and $10-15^{\circ} \mathrm{N}$. At $40-44^{\circ} \mathrm{N}$, the nss- $\mathrm{SO}_{4}^{2-}$ concentrations reached as high as $\sim 10000 \mathrm{ng} \mathrm{m}^{-3}$. Indeed, Nagao et al. (1999) suggested that most nss- $\mathrm{SO}_{4}^{2-}$ transported from northeastern and southeastern sectors to Hahajima $\left(142.10^{\circ} \mathrm{E}, 26.38^{\circ} \mathrm{N}\right)$ in the summer originated from DMS oxidation, based on their long-term measurements of nss- $\mathrm{SO}_{4}^{2-}$ and MSA. An average $\mathrm{MSA} / \mathrm{nss}^{-} \mathrm{SO}_{4}^{2-}$ ratio at $40-44^{\circ} \mathrm{N}$ in the present study is $0.021 \pm 0.018$, which is within the range $(0.02-0.04)$ of those reported for clean marine air over the western North Pacific (Nagao et al., 1999). These results support significant influences of marine biological sources on aerosols in this oceanic region. At 10$15^{\circ} \mathrm{N}$, nss- $\mathrm{SO}_{4}^{2-}$ exhibited increased concentrations up to $\sim 8000 \mathrm{ng} \mathrm{m}^{-3}$. The average MSA/nss-SO ${ }_{4}^{2-}$ ratio at this region is $0.008 \pm 0.007$, indicating an additional source for nss- $\mathrm{SO}_{4}^{2-}$. Mochida et al. (2011) reported that the plume from the eruption of Kasatochi Volcano, Aleutian Islands $\left(52.17^{\circ} \mathrm{N}, 175.51^{\circ} \mathrm{W}\right)$, on 7 August 2008 (Martinsson et al., 2009; Rix et al., 2009) may have been associated with the enhanced nss- $\mathrm{SO}_{4}^{2-}$ concentration (Uematsu et al., unpublished data). The trajectories suggest that the air masses are representative of remote marine aerosols (Fig. 1).

We note that the measured concentrations of cyanobacteria in surface seawater at $10-20^{\circ} \mathrm{N}$ were larger than those at $20-45^{\circ} \mathrm{N}$ from the same cruise observations (Suzuki et al., unpublished data). Moreover, Ooki et al. (2010) reported enhanced concentrations of methyl halide in surface seawater between $15^{\circ} \mathrm{N}$ and $20^{\circ} \mathrm{N}$ where the sea surface temperature was high, which was also revealed from the same cruise. Although the satellite-derived chlorophyll- $a$ value was low at $10-20^{\circ} \mathrm{N}$, these results indicate that the increased MSA concentrations appear to be due partly to marine biological activity by bacteria rather than phytoplankton in this subtropical region.

It should be also noted that the background marine aerosol composition can be influenced by aged ship emissions (e.g., 


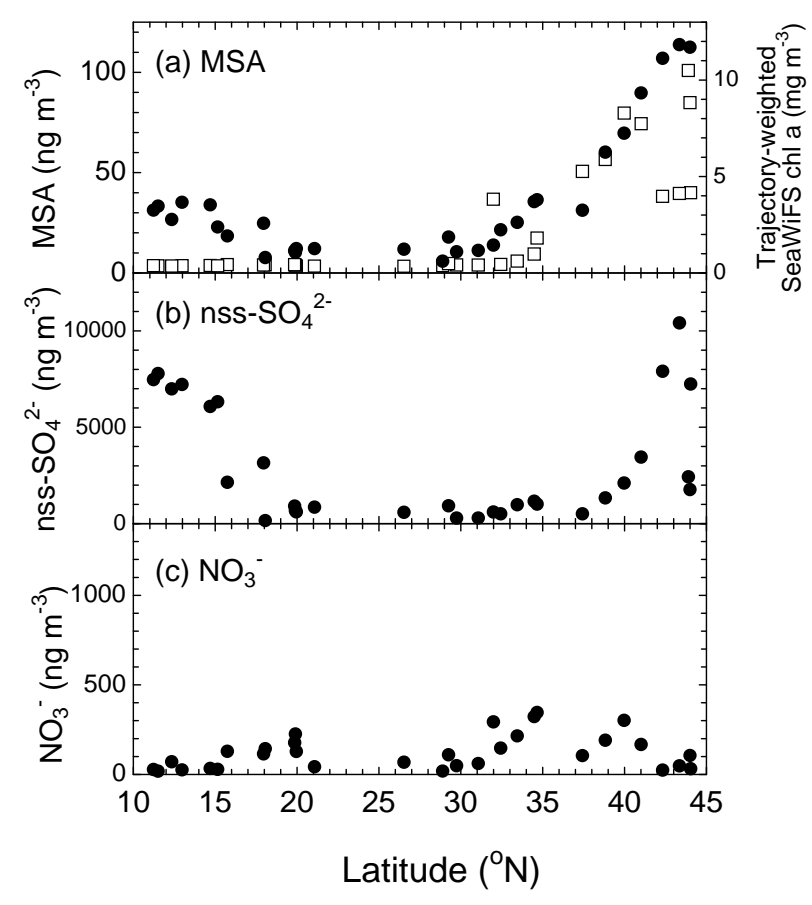

Fig. 2. Latitudinal distributions of $\mathrm{MSA}, \mathrm{nss}^{-\mathrm{SO}_{4}^{2-}}{ }^{2}$, and $\mathrm{NO}_{3}^{-}$. Also shown are 5-day back trajectory-weighted SeaWiFS chlorophyll- $a$ concentrations as square symbol.

Capaldo et al., 1999) as well as other anthropogenic emissions. However, an insignificant contribution of anthropogenic sources to the observed air masses is suggested by the low average concentrations of $\mathrm{NO}_{3}^{-}\left(116 \pm 84 \mathrm{ng} \mathrm{m}^{-3}\right)$, which are similar to those reported for clean marine aerosols over the open ocean $\left(<180 \mathrm{ng} \mathrm{m}^{-3}\right)$ (Rinaldi et al., 2009). Moreover, EC concentrations were mostly below the detection limit $\left(\sim 20 \mathrm{ngC} \mathrm{m}^{-3}\right)$, which is also similar to the concentrations reported for clean marine aerosols at Mace Head in the North Atlantic (Cooke et al., 1997). The low concentrations of these anthropogenic tracers together with the back trajectories suggest that the aerosols sampled during this study were little affected by anthropogenic sources including ship emissions.

\subsection{Temporal and spatial variations of organic nitrogen aerosols}

Figure 3 presents time series of mass concentrations of aerosol nitrogen species/components together with MSA. Latitudinal distributions of the ON, WSON, WION, and $\mathrm{DEA}^{+}$concentrations are shown in Fig. 4. During the study period, the $\mathrm{ON}$ concentrations ranged between 10 and $260 \mathrm{ngN} \mathrm{m}^{-3}$, with an average of $130 \pm 61 \mathrm{ngN} \mathrm{m}^{-3}$. The average fraction of ON to TN was as large as $67 \pm 15 \%$. Interestingly, WION $\left(112 \pm 61 \mathrm{ngN} \mathrm{m}^{-3}\right)$ was the most abundant $\mathrm{N}$ in the aerosols, accounting for $55 \pm 16 \%$ of $\mathrm{TN}$ on

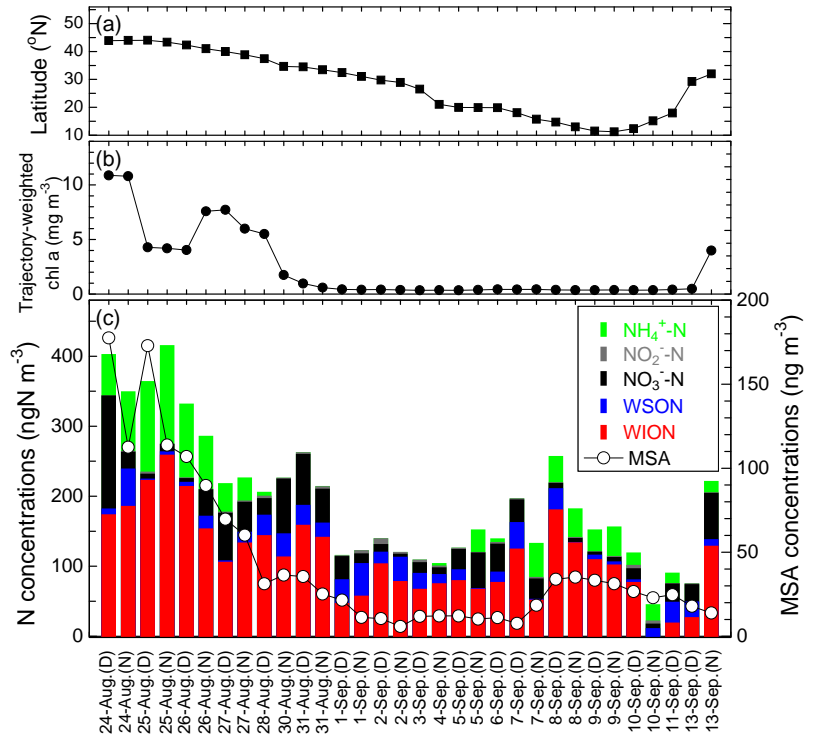

Fig. 3. Time series of (a) the average latitudinal location of the ship, (b) concentrations of trajectory-weighted chlorophyll- $a$ and (c) fractions of organic (WSON and WION) and inorganic nitrogen together with concentrations of MSA. "D" means data obtained in daytime, whereas " $\mathrm{N}$ " means data obtained in nighttime.

average. In particular, WION exhibited a maximum concentration of $260 \mathrm{ngN} \mathrm{m}^{-3}$ at $40-44^{\circ} \mathrm{N}$ (Fig. 4b), where marine biological influences on the observed aerosols were large. In this oceanic region, the average WION/ON ratio was $0.93 \pm 0.07$, which is higher than that $(0.74 \pm 0.12)$ at 10 $40^{\circ} \mathrm{N}$. In comparison to WION, WSON showed a smaller fraction, representing on average $12 \pm 10 \%$ of TN. The fraction of WSON to TN is similar to previous findings, generally ranging from $\sim 10-30 \%$ (Zhang et al., 2002; Mace et al., 2003; Nakamura et al., 2006). Overall $\mathrm{NH}_{4}^{+}$and $\mathrm{NO}_{3}^{-}$ accounted for $14 \pm 13 \%$ and $17 \pm 11 \%$ of $\mathrm{TN}$, respectively.

In general, the temporal trend of nitrogen concentrations tracked those of MSA. TN and MSA showed a linear relation with $r^{2}=0.74$, indicating a large influence of marine biological emission on aerosol $\mathrm{N}$ in the study region. In fact, Miyazaki et al. (2010a) found a bimodal size distribution of ON with two peaks at sub-micrometer and super-micrometer modes in marine aerosols over the western North Pacific in summer, where the average ON concentrations were twice more abundant in marine biologically more-influenced aerosols than in less-influenced aerosols. It should be noted that the daytime and nighttime concentrations of nitrogen species showed no distinct difference (Fig. 3). Specifically, the average ON concentration in daytime was $130 \pm 59 \mathrm{ngN} \mathrm{m}^{-3}$, which is similar to that in nighttime $\left(128 \pm 66 \mathrm{ngN} \mathrm{m}^{-3}\right)$. This result implies that the local time dependence on the temporal variations of $\mathrm{ON}$ was likely insignificant in the present study. 
As a marine biogenic organic compound of WSON, $\mathrm{DEA}^{+}$has been detected in marine aerosols (Facchini et al., 2008b; Müller et al., 2009; Sorooshian et al., 2009; Miyazaki et al., 2010a). The concentrations of aliphatic amines including $\mathrm{DEA}^{+}$measured over the northern Atlantic showed a seasonal variation, indicating that the production of amine is most likely influenced by the primary biological productivity of phytoplankton and therefore available nutrient in the ocean (Facchini et al., 2008b). Here we detected DEA ${ }^{+}$ in aerosols, with concentrations ranging from a value below the detection limit $\left(<0.1 \mathrm{ng} \mathrm{m}^{-3}\right)$ to $0.8 \mathrm{ng} \mathrm{m}^{-3}$. The $\mathrm{DEA}^{+}$ concentrations at $40-44^{\circ} \mathrm{N}\left(0.52 \pm 0.19 \mathrm{ng} \mathrm{m}^{-3}\right)$ were generally higher than those at $10-40^{\circ} \mathrm{N}\left(0.23 \pm 0.11 \mathrm{ng} \mathrm{m}^{-3}\right)$. The contribution of $\mathrm{DEA}^{+}$to WSON ranged between 0.1 and $9.8 \%$ with an average of $0.8 \%$. At $40-44^{\circ} \mathrm{N}$, both the DEA ${ }^{+}$ concentrations and $\mathrm{DEA}^{+} / \mathrm{WSON}$ ratios showed higher values compared with those at the lower latitude $\left(10-40^{\circ} \mathrm{N}\right)$, being consistent with the large influence of marine biological activity on the observed organic aerosols.

Facchini et al. (2008b) suggested that $\mathrm{DEA}^{+}$is derived from an oceanic biological source and is produced by the reaction of gaseous amines with sulfuric acid or acidic sulfates. They showed that the size distributions of $\mathrm{DEA}^{+}$in marine aerosols exhibited maxima in the accumulation mode, as is also the case for nss- $\mathrm{SO}_{4}^{2-}$, MSA, and $\mathrm{NH}_{4}^{+}$, indicating that a gas-to-particle conversion process is responsible for accumulation of ammonium salts in the fine aerosol fractions (Ge et al., 2011b). Indeed, $\mathrm{DEA}^{+}$was detected in the sub-micrometer size range of biologically more-influenced aerosols obtained in a similar oceanic region in our previous study (Miyazaki et al., 2010a). Although the size distributions of $\mathrm{DEA}^{+}$and nss- $\mathrm{SO}_{4}^{2-}$ are not available in the present study, a positive correlation between $\mathrm{DEA}^{+}$and $\mathrm{nss}_{-} \mathrm{SO}_{4}^{2-}$ $\left(r^{2}=0.52\right)$ was found in our samples, supporting the secondary formation processes of $\mathrm{DEA}^{+}$as discussed above.

Besides amine, WSON may also consist of other biologically labile components, such as amino acids (e.g., Simoneit et al., 2004) and more refractory components (e.g., humic compounds) (Cornell et al., 2003). Matsumoto and Uematsu (2005) reported that dissolved free amino acids in marine aerosols, which mostly reside in the fine mode (aerodynamic diameter less than $2.5 \mu \mathrm{m}$ ), accounted for only $<0.1 \%$ of inorganic nitrogen over the western North Pacific. Shi et al. (2010) also reported a minor contribution of free amino acids to WSON $(\sim 1 \%)$ in aerosols over the China Sea. Although detailed chemical analyses of WSON were not performed in the present study, previous studies have indicated that combined amino acids may account for a major portion of the amino compounds in aerosols (e.g., Zhang and Anastasio, 2003).

\subsection{Latitudinal distributions of organic carbon aerosols}

Figure 5 shows the latitudinal distributions of OC, WSOC, and WIOC. Similar to the latitudinal profiles of MSA and

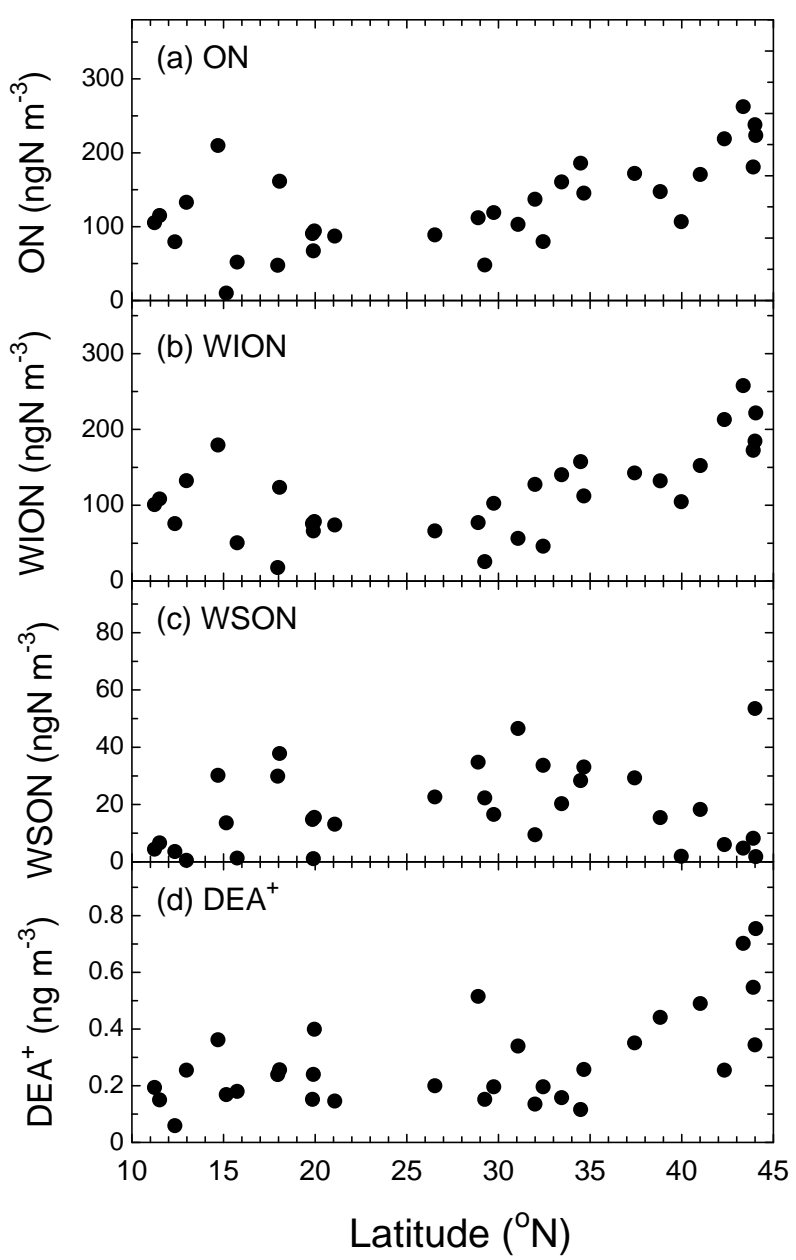

Fig. 4. Latitudinal distributions of (a) organic nitrogen (ON), (b) water-insoluble organic nitrogen (WION), (c) water-soluble organic nitrogen (WSON), and (d) diethylammonium $\left(\mathrm{DEA}^{+}\right)$.

$\mathrm{ON}, \mathrm{OC}$ and WSOC exhibited increased concentrations at $40-44^{\circ} \mathrm{N}$. In the region of $40-44^{\circ} \mathrm{N}$, an enhanced fraction of WSOC to OC was observed, ranging between 0.42 and 0.66 with an average of $0.53 \pm 0.10$. The range is similar to that $(0.46-0.55)$ found for remote marine aerosols collected over the western North Pacific in a region farther north than the present study region (Miyazaki et al., 2010b). The WSOC and MSA concentrations showed a positive correlation in the present study $\left(r^{2}=0.57\right)$, indicating an importance of secondary production of WSOC originated from marine biological sources, similar to the case of MSA. In our previous study, WSOC and oxalic acid also showed significant correlation with MSA in the sub-micrometer size range of marine biologically influenced aerosols (Miyazaki et al., 2010b), which is in agreement with the results presented here. On the other hand, Russell et al. (2010) recently observed that the ocean-derived composition in sub-micrometer marine aerosol was dominated by carbohydrate-like material 


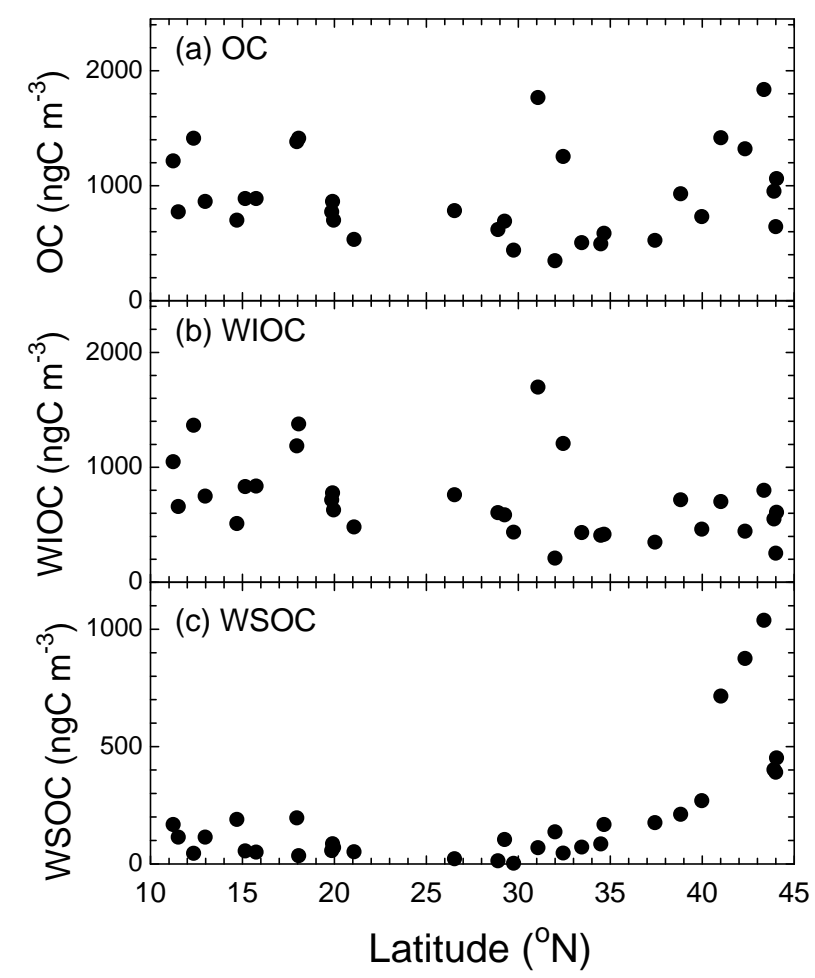

Fig. 5. Latitudinal distributions of (a) organic carbon (OC), (b) water-insoluble organic carbon (WIOC), (c) water-soluble organic carbon (WSOC).

containing organic hydroxyl groups (i.e., water-soluble organics) over the North Atlantic and Arctic oceans. In our samples, however, WSOC showed no significant correlation with $\mathrm{Na}^{+}\left(r^{2}=0.02\right)$ or local wind speeds, supporting that the majority of WSOC appears to be derived from secondary production. This point will be discussed later.

The latitudinal distribution pattern of the WIOC concentration is not apparent compared to that of WSOC. The average concentration of WIOC at 40$44^{\circ} \mathrm{N}\left(560 \pm 193 \mathrm{ngC} \mathrm{m}^{-3}\right)$ is similar to that of WSOC $\left(645 \pm 273 \mathrm{ngC} \mathrm{m}^{-3}\right)$ in the same region (Table 2). On the other hand, the WIOC concentration at $10-40^{\circ} \mathrm{N}$ $\left(660 \pm 274 \mathrm{ngC} \mathrm{m}^{-3}\right)$ is similar to that at $40-44^{\circ} \mathrm{N}$, and is substantially larger than the WSOC concetrations $\left(100 \pm 69 \mathrm{ngC} \mathrm{m}^{-3}\right)$. Overall, the concentrations of WIOC are larger by a factor of three than those observed in the Austral Ocean in summer when marine biological activity is high (Sciare et al., 2009). WIOC is mechanically produced through bubble-bursting processes from hydrophobic organic matter that accumulates in the micro layer of the ocean surface (Blanchard, 1964; Oppo et al., 1999). Indeed, WIOC in our samples showed a linear relation with $\mathrm{Na}^{+}$ $\left(r^{2}=0.37\right)$, as we observed the relation $\left(r^{2}=0.52\right)$ in the submicrometer range of particles collected in a similar oceanic region (Miyazaki et al., 2010b). The result indicates
Table 2. Average concentrations and ratios in marine aerosols sampled in the different latitudinal regions.

\begin{tabular}{lrr}
\hline & $10-40^{\circ} \mathrm{N}$ & $40-44^{\circ} \mathrm{N}$ \\
\hline $\mathrm{MSA}\left(\mathrm{ng} \mathrm{m}^{-3}\right)$ & $24 \pm 16$ & $129 \pm 37$ \\
$\mathrm{nssSO}_{4}^{2-}\left(\mathrm{ng} \mathrm{m}^{-3}\right)$ & $3060 \pm 2730$ & $6040 \pm 3400$ \\
$\mathrm{DEA}^{+}\left(\mathrm{ng} \mathrm{m}^{-3}\right)$ & $0.23 \pm 0.11$ & $0.52 \pm 0.19$ \\
$\mathrm{WION}_{\left(\mathrm{ngN} \mathrm{m}^{-3}\right)}$ & $91 \pm 44$ & $200 \pm 38$ \\
$\mathrm{WSON}\left(\mathrm{ngN} \mathrm{m}^{-3}\right)$ & $16 \pm 13$ & $19 \pm 16$ \\
$\mathrm{WIOC}\left(\mathrm{ngC} \mathrm{m}^{-3}\right)$ & $660 \pm 274$ & $560 \pm 193$ \\
$\mathrm{WSOC}\left(\mathrm{ngC} \mathrm{m}^{-3}\right)$ & $100 \pm 69$ & $645 \pm 273$ \\
$\mathrm{ON} / \mathrm{OC}$ & $0.15 \pm 0.10$ & $0.20 \pm 0.09$ \\
$\mathrm{NO}_{3}^{-}\left(\mathrm{ng} \mathrm{m}^{-3}\right)$ & $110 \pm 90$ & $63 \pm 62$ \\
$\mathrm{NH}_{4}^{+}\left(\mathrm{ng} \mathrm{m}^{-3}\right)$ & $22 \pm 19$ & $128 \pm 40$ \\
$\delta^{15} \mathrm{~N}(\% \circ)$ & $3.2 \pm 5.5$ & $5.1 \pm 1.6$ \\
$\delta^{13} \mathrm{C}(\% \circ)$ & $-20.8 \pm 4.5$ & $-22.1 \pm 1.3$ \\
\hline
\end{tabular}

that a bubble-bursting production mechanism could explain the major fraction of WIOC in the aerosols collected. It is possible that chemical aging of water-insoluble organics (e.g., oxidation of unsaturated fatty acids, and olefins to result in water-soluble organic species) primarily emitted from the ocean surface and the subsequent production of more water-soluble organics may occur in aerosols largely influenced by marine biological productivity. This could partly explain the larger fractions of WSOC in aerosols collected at $40-44^{\circ} \mathrm{N}$, which may have been transported over a higher chlorophyll- $a$ region within $12-36 \mathrm{~h}$ as discussed in Sect. 3.1.

\subsection{Nitrogen-to-carbon ratios in marine aerosols}

The relative contribution of organic nitrogen species to $\mathrm{OC}$ in aerosol mass provides insight into the origin and chemical properties of aerosol ON. The average ON/OC ratio was $0.19 \pm 0.11$ during the study period, which is higher than the typical ON/OC ratios (0.06-0.11) reported for oceanic dissolved materials (Hansell and Carlson, 2002). Miyazaki et al. (2010a) also reported higher ON/OC ratios for the oceanic materials in both the submicrometer $(0.43 \pm 0.23)$ and supermicrometer $(0.53 \pm 0.31)$ size ranges of marine aerosols obtained farther north of the present study areas in the western Pacific with high marine biological productivity. Based on the comparison with typical ON/OC ratios in oceanic dissolved materials, the present results indicate an enrichment of organic nitrogen in the marine aerosol collected in the area studied.

Furthermore, we analyzed nitrogen isotopic ratios of $\mathrm{TN}$ to investigate the contributions of marine sources to the aerosol $\mathrm{N}$ sampled here. The $\delta^{15} \mathrm{~N}$ values of TN ranged from $-2.2 \%$ to $8.9 \%$, with an average of $4.9 \pm 2.8 \%$ o. Although nitrogen isotopic analysis alone cannot provide conclusive evidence 
about atmospheric ON sources (Kelly et al., 2005), these $\delta^{15} \mathrm{~N}$ values overlap with a wide range of marine phytoplankton $(+3$ to $+12 \%$ ) (Owens, 1987). The values are also similar to those $(1.2-4.6 \%$ ) in aerosols collected in the abovementioned oceanic region with higher biological productivity in the western North Pacific (Miyazaki et al., 2010a).

To better understand the relative contributions of marine sources to the sampled aerosols, we also analyzed stable carbon isotopic ratios. In low and mid-latitudes, $\delta^{13} \mathrm{C}$ of $\mathrm{OC}$ in seawater typically ranges from -20 to $-22 \%$ o (Turekian et al., 2003), whereas the average $\delta^{13} \mathrm{C}$ of terrestrial OC sources, such as fossil fuel combustion and biomass burning, is $-26.5 \pm 1 \%$ o (e.g., Cachier et al., 1986). Based on the $\delta^{13} \mathrm{C}$ of particulate carbon over various remote oceanic areas, Cachier et al. (1986) found that most of the submicrometer particulate carbon were of continental origin, whereas coarse particles with diameter $>3 \mu \mathrm{m}$ were primarily of seawater origin. In contrast, Miyazaki et al. (2010a) found that the average $\delta^{13} \mathrm{C}$ values for the submicrometer $(-23.7 \pm 0.8 \%$ o and supermicrometer $(-23.4 \pm 0.7 \%$ ) size ranges of particulate carbon were similar in a remote oceanic region with high biological productivity. Both of these values are close to the typical $\delta^{13} \mathrm{C}$ of OC in seawater. Likewise, the $\delta^{13} \mathrm{C}$ values of -22.1 to $-20.8 \%$ with an average of $-21.0 \pm 1.9 \%$ o obtained in the present study (Table 2) are similar to those of OC in seawater. To roughly calculate the relative contribution from marine and terrestrial OC sources, we applied $\delta^{13} \mathrm{C}$ values ranging from $-22 \%$ o to $-21 \%$ o for marine $\mathrm{OC}$ and those ranging from $-27 \%$ to $-26 \%$ o for terrestrial OC typically found in the Northern Hemisphere following the isotopic mass balance equations given in previous studies (e.g., Turekian et al., 2003; Narukawa et al., 2008). Our calculation indicates that on average, marine sources contribute $88 \pm 12 \%$ of the aerosol carbon. The result supports that a majority of TC in the aerosols is derived from marine sources. Figure 6 shows a correlation between $\delta^{13} \mathrm{C}$ values and ON/OC ratios classified according to the MSA concentrations. Interestingly, the $\delta^{13} \mathrm{C}$ showed higher values (isotopically heavier) with increasing ON/OC ratios in air masses with MSA $>20 \mathrm{ng} \mathrm{m}^{-3}$. The result indicates an enrichment of nitrogen in organic aerosols in the oceanic region with high biological productivity and the preferential transfer of nitrogen-containing compounds from the sea surface to the marine atmosphere.

In general, no clear relation was found between WSOC and WSON $\left(r^{2}=0.04\right)$, which suggests differences in marine biological sources and chemical properties for these two organic fractions. As discussed in the previous section, WSOC and MSA concentrations showed positive correlation $\left(r^{2}=0.57\right)$, suggesting secondary production of organic aerosols from marine biological origin. In contrast, WSON exhibited poor correlation with MSA $\left(r^{2}=0.05\right)$. This result suggests that the sources and formation processes for the majority of WSON are different from those for MSA (i.e., DMS) and WSOC.

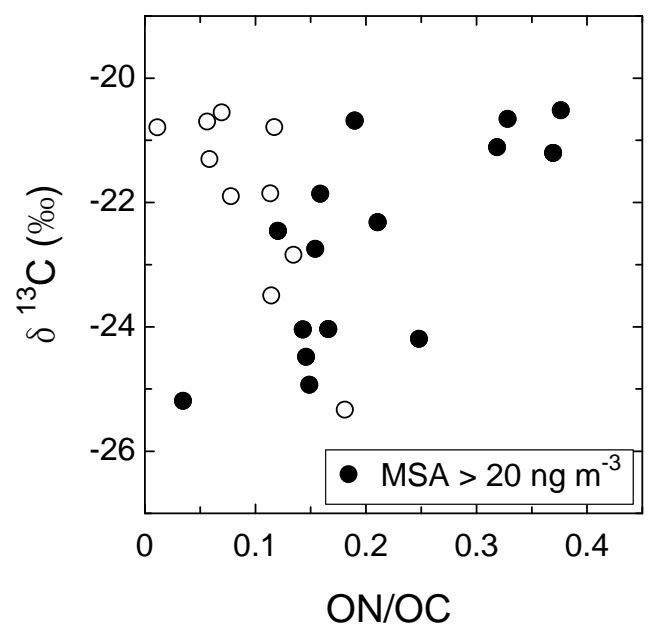

Fig. 6. Scatter plots between $\delta^{13} \mathrm{C}$ and $\mathrm{ON} / \mathrm{OC}$ ratios. Solid circles indicate the data with MSA $>20 \mathrm{ng} \mathrm{m}^{-3}$.

\subsection{Possible formation processes of WION from marine biological sources}

In this section, we discuss possible processes of WION in marine aerosols in terms of primary and secondary production. Figure 7 illustrates the WION concentrations and WION/WIOC ratios as a function of local wind speed. The WION concentrations tended to increase with increasing local wind speeds at $10-40^{\circ} \mathrm{N}$. In contrast, no relation was found between WSON and wind speed $\left(r^{2}=0.02\right.$, data not shown as a figure). These results suggest that significant fractions of WION were mechanically produced through bubble-bursting processes as a potential mechanism. Moreover, WION/WIOC ratios also increased with increasing local wind speeds (Fig. 7b), indicating that nitrogen containing organic species contributes significantly to marine organic aerosols that are likely derived from bubble-bursting processes in the studied region.

WION appears to be associated with organic particles of seawater origin, which include microorganisms, plankton debris, and inorganic particles containing adsorbed organic matter. They may also be composed of a large number of semi-transparent gel-like particles and proteins, all of which contain amino acids. Kuznetsova et al. (2005) used Coomassie blue dye to confirm that some of the colloidal gellike material surrounding bacteria and viruses was proteinaceous in Mediterranean and Atlantic marine aerosol samples. More recently, Hawkins and Russell (2010) reported chemical signatures of proteins and calcareous phytoplankton as well as polysaccharides in hydrophobic marine aerosols collected in the Arctic and southeastern Pacific using NearEdge Absorption X-ray Fine Structure (NEXAFS) spectromicroscopy. The present finding that the fraction of WION is large in marine biologically influenced aerosols is supported by these previous studies. 

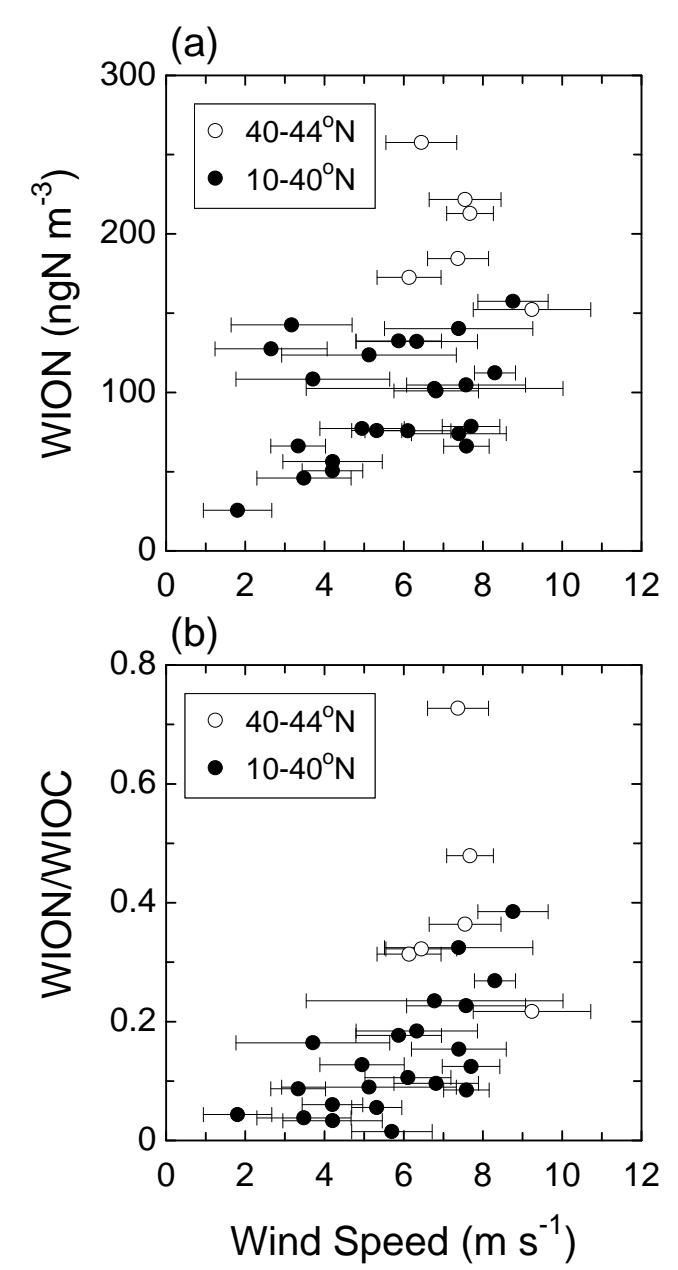

Fig. 7. Relations of (a) WION concentrations and (b) WION/WIOC ratios with local wind speed at $40-44^{\circ} \mathrm{N}$ (open circles) and 10 $40^{\circ} \mathrm{N}$ (solid circles). Values and bars for wind speed indicate averages and standard deviations, respectively, during each sampling time.

At $40-44^{\circ} \mathrm{N}$, the relation between WION and local wind speeds, although the values of these parameters are larger, is less evident compared to that at $10-40^{\circ} \mathrm{N}$ (Fig. 7). On the basis of laboratory experiments on nascent sea spray aerosols, Facchini et al. (2008a) reported that sea spray organics tend to aggregate and form colloids or suspended particles, which makes the definition of water solubility a complex issue. Considering the significance of secondary production at $40-44^{\circ} \mathrm{N}$ as discussed above, secondary formation of ON associated with marine emissions of gaseous precursors (e.g., biogenic volatile organic compounds and $\mathrm{NH}_{3}$ ) is another possibility that could partly explain the increase of WION. As one possible process for secondary formation of nitrogen-containing organic aerosols, Galloway et al. (2009) recently reported that glyoxal uptake onto ammonium sulfate seed aerosol can irreversibly form C-N compounds. In

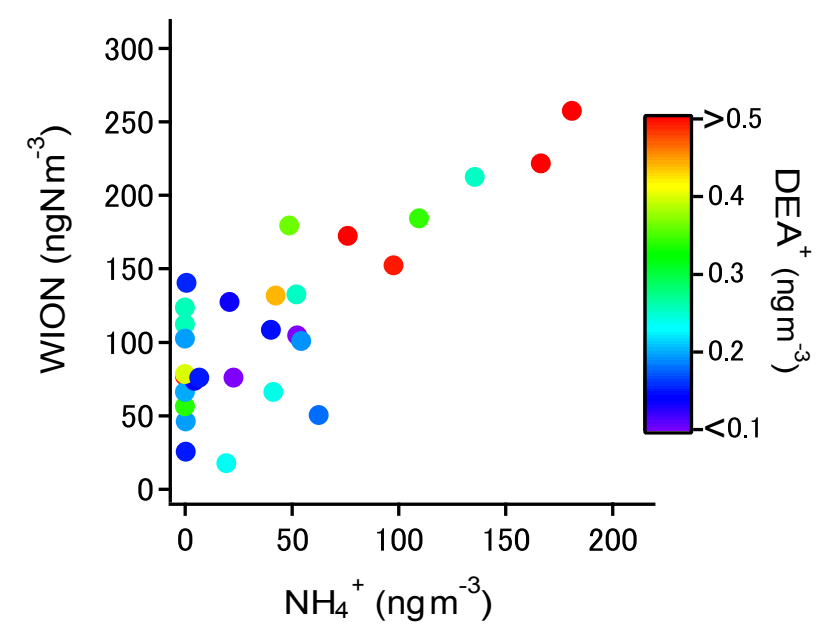

Fig. 8. A linear relation between WION and $\mathrm{NH}_{4}^{+}$, color-coded according to the concentration of $\mathrm{DEA}^{+}$.

fact, glyoxal and methylglyoxal were detected in aerosols from marine biological origin in the similar oceanic region in our previous studies (Miyazaki et al., 2010b). Figure 8 illustrates the linear relation between WION and $\mathrm{NH}_{4}^{+}$, colorcoded according to the $\mathrm{DEA}^{+}$concentration. The WION concentration was positively correlated with $\mathrm{NH}_{4}^{+}$, particularly under the large influence of marine biological activity (i.e., $\mathrm{DEA}^{+}>0.3 \mathrm{ng} \mathrm{m}^{-3}$ ). The positive correlation indicates that the possible formation of WION is related to ammonium salts in marine biologically influenced aerosol.

The substantial amount of WION in marine biologically influenced aerosols found in the present study may provide insights into chemical composition of WIOC, which is still mostly uncharacterized with the exception of fatty acids (Mochida et al., 2002), n-alkanes and fatty alcohols (Kawamura et al., 2003). Chemical characterizations of WION as well as WSON in aerosols from marine biological sources at a molecular level and the mechanisms of primary and secondary formation of WION require further study.

\section{Conclusions}

Latitudinal distributions of organic nitrogen $(\mathrm{ON})$ and organic carbon (OC) as well as isotopic ratios of total nitrogen $(\mathrm{TN})$ and total carbon (TC) were measured in marine aerosols collected in the western North Pacific in summer 2008. Increased concentrations of methanesulfonic acid (MSA) and diethylammonium $\left(\mathrm{DEA}^{+}\right)$at $40-44^{\circ} \mathrm{N}$ and subtropical regions $\left(10-20^{\circ} \mathrm{N}\right)$ together with averaged satellite chlorophyll- $a$ data and 5-day back trajectories suggest significant influences of marine biological activities on aerosols in these regions. ON exhibited increased concentrations (up to $260 \mathrm{ngN} \mathrm{m}^{-3}$ ) in the marine biologically influenced aerosols. Water-insoluble organic nitrogen (WION) was found to be 
the most abundant $\mathrm{N}$ in the marine aerosols, accounting for $55 \pm 16 \%$ of total aerosol $\mathrm{N}$ on average. In particular, the average WION/ON ratio was as high as $0.93 \pm 0.07$ at 40 $44^{\circ} \mathrm{N}$. Overall WSON accounted for $\sim 12 \%$ of total N. These results suggest that marine biological sources significantly contributed to $\mathrm{ON}$, a majority of which is composed of waterinsoluble fractions in the study region. It should be noted that if organic compounds having nitrogen atoms adjacent to carbon atom in their molecular structure are present in the sampled aerosols, some components associated with WSON may not be determined quantitatively under our operating conditions. This may lead to an uncertainty of WSON being underestimated and thus, WION may be overestimated.

The stable carbon isotopic analysis indicated that, on average, marine-derived carbon accounted for $\sim 88 \pm 12 \%$ of total carbon in the aerosols. Moreover, the stable carbon isotopic ratios showed higher values (from -22 to $-20 \%$ ) when ON/OC ratios increased from 0.15 to 0.35 in marine biologically influenced aerosols. The results clearly indicate an enrichment of nitrogen in organic aerosols originated from an oceanic region with high biological productivity and preferential transfer of nitrogen-containing organic compounds from the sea surface to the marine atmosphere. Furthermore, both WION concentrations and WION/WIOC ratios tended to increase with increasing local wind speeds, indicating that sea-to-air emissions of ON via sea spray contribute significantly to the marine organic aerosols over the study region.

Acknowledgements. We thank the researchers and crew of the R/V Hakuho-maru for their help with the observations. This research was supported by grants-in-aid for scientific research (21710001) and for the priority area "Western Pacific Air-Sea Interaction Study (W-PASS)" (18067005) from the Ministry of Education, Culture, Sports, Science and Technology (MEXT), Japan. This research was also supported by the Environment Research and Technology Development Fund (B-0903) of the Ministry of the Environment, Japan.

Edited by: M. Kanakidou

\section{References}

Aller, J. Y., Kuznetsova, M. R., Jahns, C. J., and Kemp, P. F.: The sea surface microlayer as a source of viral and bacterial enrichment in marine aerosols, J. Aerosol Sci., 36, 801-812, 2005.

Ayers, G. P. and Gras, J. L.: Seasonal relationship between cloud condensation nuclei and aerosol methanesulphonate in marine air, Nature, 353, 834-835, 1991.

Blanchard, D. C.: Sea-to-air transport of surface active material, Science, 146, 396-397, 1964.

Cachier, H., Buat-Ménard, M. P., Fontugne, M., and Chesselet, R.: Long-range transport of continentally-derived particulate carbon in the marine atmosphere: Evidence from stable carbon isotope studies, Tellus B, 38, 161-177, 1986.

Capaldo, K., Corbett, J. J., Kasibhatla, P., Fischbeck, P., and Pandis, S. N.: Effects of ship emissions on sulphur cycling and radiative climate forcing over the ocean, Nature, 400, 743-746, 1999.
Cooke, W. F., Jennings, S. G., and Spain, T. G.: Black carbon measurements at Mace Head, 1989-1996, J. Geophys. Res., 102, 25339-25346, 1997.

Cornell, S. E., Jickells, T. D., Cape, J. N., Rowland, A. P., and Duce, R. A.: Organic nitrogen deposition on land and coastal environments: a review of methods and data, Atmos. Environ., 37, 2173-2191, 2003.

Duce, R. A., LaRoche, J., Altieri, K., Arrigo, K. R., Baker, A. R., Capone, D. G., Cornell, S., Dentener, F., Galloway, J., Ganeshram, R. S., Geider, R. J., Jickells, T., Kuypers, M. M., Langlois, R., Liss, P. S., Liu, S. M., Middelburg, J. J., Moore, C. M., Nickovic, S., Oschlies, A., Pedersen, T., Prospero, J., Schlitzer, R., Seitzinger, S., Sorensen, L. L., Uematsu, M., Ulloa, O., Voss, M., Ward, B., and Zamora, L.: Impacts of atmospheric anthropogenic nitrogen on the open ocean, Science, 320, 893-897, 2008.

Facchini, M. C., Rinaldi, M., Decesari, S., Carbone, C., Finessi, E., Mircea, M., Fuzzi, S., Ceburnis, D., Flanagan, R., Nilsson, E. D., de Leeuw, G., Martino, M., Woeltjen, J., and O'Dowd, C. D.: Primary submicron marine aerosol dominated by insoluble organic colloids and aggregates, Geophys. Res. Lett., 35, L17814, doi:10.1029/2008GL034210, 2008a.

Facchini, M. C., Decesari, S., Rinaldi, M., Carbone, C., Finessi, E., Mircea, M., Fuzzi, S., Moretti, F., Tagliavini, E., Ceburnis, D., and O'Dowd, C. D.: Important source of marine secondary organic aerosol from biogenic amines, Environ. Sci. Technol., 42, 9116-9121, 2008b.

Galloway, M. M., Chhabra, P. S., Chan, A. W. H., Surratt, J. D., Flagan, R. C., Seinfeld, J. H., and Keutsch, F. N.: Glyoxal uptake on ammonium sulphate seed aerosol: reaction products and reversibility of uptake under dark and irradiated conditions, Atmos. Chem. Phys., 9, 3331-3345, doi:10.5194/acp-9-3331-2009, 2009.

Ge, X., Wexler, A. S., and Clegg, S. L.: Atmospheric Amines - Part I. A review, Atmos. Environ., 45, 524-546, $2011 \mathrm{a}$.

Ge, X., Wexler, A. S., and Clegg, S. L.: Atmospheric Amines Part II. Thermodynamic properties and gas/particle partitioning, Atmos. Environ., 45, 561-577, $2011 \mathrm{~b}$.

Hansell, D. A. and Carlson, C. A.: Biogeochemistry of marine dissolved organic matter, Academic Press, New York, 3, p. 65, 2002.

Hawkins, L. N. and Russell, L. M.: Polysaccharides, proteins, and phytoplankton fragments: four chemically distinct types of marine primary organic aerosol classified by single particle spectromicroscopy, Adv. Meteorol., 2010, 612132, doi:10.1155/2010/612132, 2010.

Hawkins, L. N., Russell, L. M., Covert, D. S., Quinn, P. K., and Bates, T. S.: Carboxylic acids, sulfates, and organosulfates in processed continental organic aerosol over the southeast $\mathrm{Pa}$ cific Ocean during VOCALS-REx 2008, J. Geophys. Res., 115, D13201, doi:10.1029/2009JD013276, 2010.

Kawamura, K., Ishimura, Y., and Yamazaki, K.: Four years' observations of terrestrial lipid class compounds in marine aerosols from the western North Pacific, Global Biogeochem. Cy., 17(1), 1003, doi:10.1029/2001GB001810, 2003.

Kawamura, K., Kobayashi, M., Tsubonuma, N., Mochida, M., Watanabe, T., and Lee, M.: Organic and inorganic compositions of marine aerosols from East Asia: Seasonal variations of water soluble dicarboxylic acids, major ions, total carbon and nitro- 
gen, and stable $\mathrm{C}$ and $\mathrm{N}$ isotopic composition, in: Geochemical Investigation in Earth and Space Science; A Tribute to Issac R. Kaplan, The Geochemical Society, 9, Elsevier, 243-265, 2004.

Kelly, S. D., Stein, C., and Jickells, T. D.: Carbon and nitrogen isotopic analysis of atmospheric organic matter, Atmos. Environ., 39, 6007-6011, 2005.

Kuznetsova, M., Lee, C., and Aller, J.: Characterization of the proteinaceous matter in marine, Marine Chem., 96, 359-377, 2005.

Leck., C. and Bigg, E. K.: Aerosol production over remote marine areas—a new route, Geophys. Res. Lett., 26, 3577-3580, 1999.

Mace, K. A., Duce, R. A., and Tindale, N. W.: Organic nitrogen in rain and aerosol at Cape Grim, Tasmania, Australia, J. Geophys. Res. Atmos., 108(D11), 4338, doi:10.1029/2002JD003051, 2003.

Martinsson, B. G., Brenninkmeijer, C. A. M., Carn, S. A., Hermann, M., Heue, K.-P., van Velthoven, P. F. J., and Zahn, A.: Influence of the 2008 Kasatochi volcanic eruption on sulfurous and carbonaceous aerosol constituents in the lower stratosphere, Geophys. Res. Lett., 36, L12813, doi:10.1029/2009GL038735, 2009.

Matsumoto, K. and Uematsu, M.: Free amino acids in sizefractionated marine aerosols over the remote ocean, Atmos. Environ., 39, 2163-2170, 2005.

Milne, P. J. and Zika, R. G.: Amino acid nitrogen in atmospheric aerosols: occurrence, sources and photochemical modification, J. Atmos. Chem., 16, 361-398, 1993.

Miyazaki, Y., Kawamura, K., and Sawano, M.: Size distributions of organic nitrogen and carbon in remote marine aerosols: Evidence of marine biological origin based on their isotopic ratios, Geophys. Res. Lett., 37, L06803, doi:10.1029/2010GL042483, 2010a.

Miyazaki, Y., Kawamura, K., and Sawano, M.: Size distributions and chemical characterization of water-soluble organic aerosols over the western North Pacific in summer, J. Geophys. Res., 115, D23210, doi:10.1029/2010JD014439, 2010b.

Mochida, M., Kitamori, Y., Kawamura, K., Nojiri, Y., and Suzuki, K.: Fatty acids in the marine atmosphere: Factors governing their concentrations and evaluation of organic films on sea salt particles, J. Geophys. Res., 107(D17), 4325, doi:10.1029/2001JD001278, 2002.

Mochida, M., Nishita-Hara, C., Furutani, H., Miyazaki, Y., Jung, J., Kawamura, K., and Uematsu, M.: Hygroscopicity and cloud condensation nucleus activity of marine aerosol particles over the western North Pacific, J. Geophys. Res., 116, D06204, doi:10.1029/2010JD014759, 2011.

Müller, C., Iinuma, Y., Karstensen, J., van Pinxteren, D., Lehmann, S., Gnauk, T., and Herrmann, H.: Seasonal variation of aliphatic amines in marine sub-micrometer particles at the Cape Verde islands, Atmos. Chem. Phys., 9, 9587-9597, doi:10.5194/acp-99587-2009, 2009.

Myriokefalitakis, S., Vignati, E., Tsigaridis, K., Papadimas, C., Sciare, J., Mihalopoulos, N., Facchini, M. C., Rinaldi, M., Dentener,F. J., Ceburnis, D., Hatzianastasiou, N., O’Dowd, C. D., van Weele, M., and Kanakidou, M.: Global modeling of the oceanic source of organic aerosols, Adv. Meteorol., 2010, 939171, doi:10.1155/2010/939171, 2010.

Nagao, I., Matsumoto, K., and H. Tanaka, H.: Characteristics of dimethylsulfide, ozone, aerosols, and cloud condensation nuclei in air masses over the northwestern Pacific Ocean, J. Geophys.
Res., 104(D9), 11675-11693, 1999.

Nakamura, T., Ogawa, H., Kumar, D. M., and Uematsu, M.: Contribution of water soluble organic nitrogen to total nitrogen in marine aerosols over the East China Sea and western North Pacific, Atmos. Environ., 40, 7259-7264, 2006.

Narukawa, M., Kawamura, K., Li, S.-M., and Bottenheim, J. W.: Stable carbon isotopic ratios and ionic composition of the high-Arctic aerosols: An increase in $\delta 13 \mathrm{C}$ values from winter to spring, J. Geophys. Res., 113, D02312, doi:10.1029/2007JD008755, 2008.

O’Dowd, C. D., Facchini, M. C., Cavalli, F., Ceburnis, D., Mircea, M., Decesari, S., Fuzzi, S., Yoon, Y. J., and Putaud, J.-P.: Biogenically driven organic contribution to marine aerosol, Nature, 431, 676-680, 2004.

Ooki, A., Tsuda, A., Kameyama, S., Takeda, S., Itoh, S., Suga, T., Tazoe, H., Okubo, A., and Yokouchi, Y.: Methyl halides in surface seawater and marine boundary layer of the Northwest Pacific, J. Geophys. Res., 115, C10013, doi:10.1029/2009JC005703, 2010.

Oppo, C., Bellandi, S. degli Innocenti, N., Stortini, A. M., Loglio, G., Schiavuta, E., and Cini, R.: Surfactant components of marine organic matter as agents for biogeochemical fractionation and pollutant transport via marine aerosols, Mar. Chem., 63, 235253, 1999.

Owens, N. J. P.: Natural variations in ${ }^{15} \mathrm{~N}$ in the marine environment, Advances in Marine Biology, 24, 389-451, 1987.

Rinaldi, M., Facchini, M. C., Decesari, S., Carbone, C., Finessi, E., Mircea, M., Fuzzi, S., Ceburnis, D., Ehn, M., Kulmala, M., de Leeuw, G., and O'Dowd, C. D.: On the representativeness of coastal aerosol studies to open ocean studies: Mace Head - a case study, Atmos. Chem. Phys., 9, 9635-9646, doi:10.5194/acp-99635-2009, 2009.

Rinaldi, M., Decesari, S., Finessi, E., Giulianelli, L., Carbone, C., Fuzzi, S., O'Dowd, C. D., Ceburnis, D., and Facchini, M. C.: Primary and secondary organic marine aerosol and oceanic biological activity: Recent results and new perspectives for future studies, Adv. Meteorol., 2010, 310682, doi:10.1155/2010/310682, 2010.

Rix, M., Valks, P., Hao, N., van Geffen, J., Clerbaux, C., Clarisse, L., Coheur, P.-F., Loyola, D. G., Erbertseder, T., Zimmer, W., and Emmadi, S.: Satellite monitoring of volcanic sulfur dioxide emissions for early warning of volcanic gazards, IEEE J. Selec. Top. Appl. Earth Obs. Remote Sens, 2, 196-206, 2009.

Rusell, L. M., Hawkins, L. N., Frossard, A. A., Quinn, P. K., and Bates, T. S.: Carbohydrate-like composition of submicron atmospheric particles and their production from ocean bubble bursting, Proceedings of the National Academy of Sciences of the United States of America, 107, 15, 6652-6657, 2010.

Schade, G. W. and Crutzen, P. J.: Emission of aliphatic amines from animal husbandry and their reactions: Potential source of $\mathrm{N}_{2} \mathrm{O}$ and HCN, J. Atmos. Chem., 22, 319-346, 1995.

Sciare, J., Favez, O., Sarda-Estève, R., Oikonomou, K., Cachier, H., and Kazan, V.: Long-term observations of carbonaceous aerosols in the Austral Ocean atmosphere: Evidence of a biogenic marine organic source, J. Geophys. Res., 114, D15302, doi:10.1029/2009JD011998, 2009.

Shi, J., Gao, H., Qi, J., Zhang, J., and Yao, X.: Sources, compositions and distributions of water-soluble organic nitrogen in aerosols over the China Sea, J. Geophys. Res., 115, D17303, 
doi:10.1029/2009JD013238, 2010.

Simoneit, B. R. T., Kobayashi, M., Mochida, M., Kawamura, K., and Huebert, B. J.: Aerosol particles collected on aircraft flights over the northwestern Pacific region during the ACE-Asia campaign: Composition and major sources of the organic compounds, J. Geophys. Res., 109, D19S09, doi:10.1029/2004JD004565, 2004.

Sorooshian, A., Padró, L. T., Nenes, A., Feingold, G., McComiskey, A., Hersey, S. P., Gates, H., Jonsson, H. H., Miller, S. D., Stephens, G. L., Flagan, R. C., and Seinfeld, J. H.: On the link between ocean biota emissions, aerosol, and maritime clouds: Airborne, ground, and satellite measurements off the coast of California, Global Biogeochem. Cy., 23, GB4007, doi:10.1029/2009GB003464, 2009.

Spracklen, D. V., Arnold, S. R., Carslaw, K. S., Sciare, J., and Pio, C.: Globally significant oceanic source of organic carbon aerosol, Geophys. Res. Lett., 35, L12811, doi:10.1029/2008GL033359, 2008.
Turekian, V. C., Macko, S. A., and Keene, W. C.: Concentrations, isotopic compositions, and sources of size-resolved, particulate organic carbon and oxalate in near-surface marine air at Bermuda during spring, J. Geophys. Res., 108(D5), 4157, doi:10.1029/2002JD002053, 2003.

Vignati, E., Facchini, M. C., Rinaldi, M., Scannell, C., Ceburnis, D., Sciare, J., Kanakidou, M., Myriokefalitakis, S., Dentener, F., and O'Dowd, C. D.: Global scale emission and distribution of sea-spray aerosol: Sea-salt and organic enrichment, Atmos. Environ., 44, 670-677, 2010.

Zhang, Q. and Anastasio, C.: Free and combined amino compounds in atmospheric fine particles (PM2.5) and fog waters from Northern California, Atmos. Environ., 37, 2247-2258, 2003.

Zhang, Q., Anastasio, C., and Jimenez-Cruz, M.: Watersoluble organic nitrogen in atmospheric fine particles $\left(\mathrm{PM}_{2.5}\right)$ from northern California, J. Geophys. Res., 107(D11), 4112, doi:10.1029/2001JD000870, 2002. 